\title{
A SCATHEL WEED PARTHENIUM HYSTEROPHORUS MENACING NATURAL AND AGRO ECOSYSTEM IN KANCHANPUR, NEPAL
}

\author{
M. Joshi, U. Bhat and M.D. Bhatt* \\ *Department of Botany, Siddhanath Science Campus (TU), Mahendranagar, Nepal \\ Correspondence author email:bhattmdrp@gmail.com
}

\begin{abstract}
Eighty plant species were recorded along with Parthenium hysterophorus from different sites, of which 75 species were recorded from site 1,73 species from site 2 and 77 species from site 3 .On the basis of density and IVI, 14 plant species were recorded as dominant (Density $>12$ ) among study sites. Alysicarpus vaginalis (17.3), Casia tora (17.0), Cynodon dactylon (19.7), Cyperus rotundus (13.7), Evolvulus nummularis (32.3), Mecardonia procumbens (20.6), Oxalis corniculata (18.6), Parthenium hysterophorus (396.0) and Zizyphus mauritiana (12.0) at site 1. Cynodon dactylon (14.7), Dactyloctenium aegyptium (13.0), Cyperus rotundus (13.0) and Parthenium hysterophorus (135.3) species at site 2 and Cynodon dactylon (19.0), Cyperus rotundus (29.0), Desmodium triflorum (12.6), Digitaria sanguinalis (17.7), Euphorbia hirta (18.6), Evolvulus nummularis (46.6) and Lathirus athaca (12.6) and Parthenium hysterophorus (303.6) species at site 3. The most common species were Evolvulus nummularis, Cynodon dactylon, Imperata cylindrica, Cannabis sativa, Oxalis corniculata, Ageratum haustorium, Lippia nudiflora, Euphorbia hirta, Portulica olearacea, and Solanum xanthocarpum in all sites. From this survey on different sites of Mahendranagar the result obtained as; the maximum density of Parthenium was recorded $396.67 \mathrm{~m}^{-2}, 135.3 \mathrm{~m}^{-2}$ and $303.7 \mathrm{~m}^{-2}$ at site 1, 2 and 3, respectively. The sign of higher density of Parthenium at site 1 proves the favorable conditions i.e. sandy dry and gravel soil with high temperature. The species richness decreased on increase of Parthenium density in all study sites. Socio-economic surveys recorded health problems for cattle such as skin allergies, wounds, eye redness, and wounds around the mouth, loss of thirst and loss of appetite. The height of the Parthenium was recorded $196.4 \pm 2.96 \mathrm{~cm}, 176 \pm 7.50 \mathrm{~cm}$ and $96.0 \pm 9.31 \mathrm{~cm}$ at site1, 2 and 3, respectively. Similarly, highest leaf area, petiole length and circumference was recorded $263.6 \pm 22.26 \mathrm{~cm}^{2}, 8.16 \pm 0.77 \mathrm{~cm}$ and $7.72 \pm 0.64 \mathrm{~cm}$, respectively at site 1,2 and 3 , respectively.
\end{abstract}

Key words: Important Value Index (IVI), Invasion, species composition, weed.

\section{INTRODUCTION}

Invasive species are recognized as one of the major threats to native species and ecosystems around the world (Kathiresan, 2004; Kathiresan et al., 2005). Invasive species are of concern because of their capability of spreading fast, their high competitiveness and ability to colonize new areas within short periods. The major invasive species Parthenium hysterophorous is tremendously distributed. Parthenium belonging to the family Asteriaceae, is an annual herb, erect; the stem is branched and covered with trichomes. Flowering occurs about a month after germination. Seeds do not have dormancy period and are capable of germinating anytime when moisture is available. It can produce large amount of seeds (up to 100,000 per plant) (CRC, 2003). The seeds of Parthenium hysterophorous is mainly dispersed through water currents, 
animals and the movement of vehicles, machinery, livestock, grain, stock feed and other products.Parthenium hysterophorus, commonly known as false ragweed, star weed, bitter weed, white top, bastard, feverfew, congress grass etc. Parthenium hysterophorus is of particular concern because of its invasive and allopathic properties. According to Kanchan (1975), the concentration of allelochemicals viz. parthenin, caffeic acid and pcoumaric acid which are present in Parthenium have serious allopathic effects.

The First occurrence of the weed in Nepal was reported by Malla from Trishuli in 1967 (Tiwari et al., 2005). Pathenium weed is also known to have caused human health problems like asthma, bronchitis, dermatitis and hay fever (Sriamaet al., 1991; Kololgi et al., 1997). Direct Contact with Parthenium hysterophorus causes inflamed udder, fever and rushes in cows and allergic inflammation in the mouth of other cattle. Buffalo and bull calves suffer from toxicity, ulceration in mouth and digestive tracts (Chippendale and Panetta, 1994). Parthenium offers a big challenge to all attempts of control because of its high regeneration capacity, production of huge amount of seeds, high seed germination ability and extreme adaptability to a wide range of ecosystems. Although few herbicides can control the weeds, the huge amount of Parthenium cannot be controlled economically by chemicals. However, in Nepal little data of scientific investigation have little information regarding Parthenium, its impact and about its management. It is hoped that this study comes up with information and may develop management options capable of controlling aggressive invasion of Parthenium.

\section{MATERIALS AND METHODS}

\section{Study Site}

Kanchanpur is the Far Western Terai district of Nepal. Geographically Far Western Development Region lies between $28^{\circ} 31^{\prime}$ to $30^{\circ} 12^{\prime}$ 'North latitudes and $80^{\circ} 4^{\prime}$ 'to $81^{\circ} 45^{\prime}$ East longitudes. The altitude varies from 176 to 7134 above the mean sea level (amsl). In Mahendranagar, the present investigation area is situated at $28^{\circ} 32^{\prime}$ to $29^{\circ} 28^{\prime} \mathrm{N}$ latitudes and $80^{\circ} 03^{\prime}$ to $80^{\circ} 33^{\prime} \mathrm{E}$ longitudes with an altitudinal range of 76 to 300 amsl. The present survey was planned and carried out in different sites at Mahendranagar on three different land types, viz. roadsides (site 1), agro-fields (site 2) and public parks (site 3).During this study the average maximum temperature ranged from $21.1^{\circ} \mathrm{C}$ to $38.4^{\circ} \mathrm{C}$ and average minimum temperature was recorded $7.5^{\circ} \mathrm{C}$. The total annual rainfall was recorded $2276.6 \mathrm{~mm}$ at Mahendranagar.

\section{Data collection}

The life cycle of Parthenium completes within a year. Hence, survey was carried out during July, 2016 to July, 2017. The present survey was carried out by systematic visits of the study site at definite regular interval of a month. During the visits, the natural habit, growth form, phenology, composition of plant species with Parthenium was determined by visual observation. Quadrats of $1 \times 1 \mathrm{~m}$ size were laid down randomly in the study sites for species composition. In these stands, three replicates were executed using the appropriate size of quadrats. The species with higher IVI value were considered as dominant species with Parthenium. Collected plant species were identified with the help of authentic literatures. Ten fresh and healthy plants were selected randomly from each site and height of plants from base to top was measured by scale in centimeter. For the measurement of leaf area, ten fully expanded leaves of Parthenium 
were collected from each site on maturation and calculation was done as per Zobel et al. (1987). Density and frequency was calculated as per Misra (1968). The Importance Value Index (IVI) was calculated as per Curtis and McIntosh (1951) for each species. Socio-economic surveys were conducted in all study sites using open ended, semi structured questionnaires involving farmers, cattle grazers, fodder collectors, community forest users' group, and health workers, to understand the public opinions. A total of 41 interviews were conducted in the study sites. Furthermore, public discussions were held with different target groups in order to raise awareness about the impacts of Parthenium.

\section{RESULTS}

Composition of plant species with Parthenium

Table 1: Diversity composition of plant species with their density and IVI in different study sites.

\begin{tabular}{|c|c|c|c|c|c|c|c|}
\hline \multirow{2}{*}{ Name of plant species } & \multirow{2}{*}{ Family } & \multicolumn{2}{|c|}{ Site 1} & \multicolumn{2}{|c|}{ Site 2} & \multicolumn{2}{|c|}{ Site 3} \\
\hline & & $\mathrm{D}^{*}$ & IVI & $\mathrm{D}^{*}$ & IVI & $\mathrm{D}^{*}$ & IVI \\
\hline Acyranthes aspera L. & Amaranthaceae & 2.7 & 4.2 & - & - & 2.0 & 4.1 \\
\hline Ageratum haustorium L. & Asteraceae & 5.3 & 17.0 & 4.3 & 18.6 & 2.7 & 4.2 \\
\hline Ajuga bracteasu Wall. ex Benth. & Labiatae & 4.3 & 4.4 & 4.6 & 4.6 & 2.0 & 4.1 \\
\hline Alternanthera sesessilis (L.) DC. & Amaranthaceae & 3.6 & 4.3 & 5.3 & 17.5 & 5.3 & 17.1 \\
\hline Alysicarpus vagenalis (L.) DC. & Leguminosae & 17.3 & 18.4 & 2.0 & 4.4 & 9.0 & 17.6 \\
\hline Amaranthus spinous L. & Amaranthaceae & 9.0 & 17.4 & 1.0 & 3.7 & 1.3 & 5.1 \\
\hline Amaranthus viridusRoxb. & Amaranthaceae & 9.0 & 17.4 & 10.7 & 18.6 & 5.0 & 17.0 \\
\hline Anagallis arvensis L. & Primulaceae & 3.0 & 4.2 & 9.0 & 18.2 & 5.0 & 16.6 \\
\hline Argemon Mexicana Linn. & Papaveraceae & 10.3 & 17.6 & 5.7 & 17.6 & 6.0 & 17.2 \\
\hline Artemisia vulgaris Linn. & Asteraceae & 1.3 & 4.1 & 11.6 & 18.7 & 0.3 & 3.0 \\
\hline Azadirachta indica $\mathrm{L}$. & Meliaceae & 0.6 & 3.5 & 0.3 & 3.1 & - & - \\
\hline Bacopa monnieri (L.) Tannel & Plantaginaceae & - & - & 6.3 & 17.7 & 0.7 & 3.5 \\
\hline Bidens pilosa $\mathrm{L}$ & Asteraceae & 8.7 & 17.4 & 1.3 & 4.5 & 6.0 & 17.2 \\
\hline Brachieria ramose (L.) Stapf. & Poaceae & 10.0 & 17.6 & 6.0 & 17.9 & 6.7 & 17.3 \\
\hline Calotropis gigantea Linn.R.Br & Asclepidaceae & 7.3 & 17.2 & 0.3 & 3.1 & 2.0 & 4.2 \\
\hline Cannabis sativa Linn. & Cannabiaceae & 10.0 & 17.6 & 4.7 & 4.9 & 2.7 & 16.7 \\
\hline Cassia tora $\mathrm{L}$. & Leguminosae & 17.0 & 18.4 & 1.6 & 3.8 & 3.3 & 4.3 \\
\hline Centella asiatica (L.) Urb. & Apiaceae & 5.3 & 17.0 & 0.3 & 3.07 & 7.0 & 17.3 \\
\hline
\end{tabular}

are enumerated along with density and IVI. A total of 80 species along with Parthenium belonging to 31 different families. In the present survey, the dominant families found as Poaceae (12 species), Asteraceae ( 9 species), Cyperaceae (6 species), Leguminosae (5 species), Amaranthaceae (4 species), Commelinaceae (3 species) (Table 1). From this survey on different sites of Mahendranagar the result obtained as; the maximum density of Parthenium was recorded $396.67 \mathrm{~m}^{-2}$ at site $1,135.3 \mathrm{~m}^{-2}$ site 2 and $303.7 \mathrm{~m}^{-2}$ at site 3 . The sign of higher density of Parthenium at site 1 proves the favorable conditions i.e. sandy dry and gravel soil with high temperature. The species richness decreased on increase of Parthenium density in all study sites (Table 1). 
Chenopodium album $\mathrm{L}$.

Cissampelos pareira $\mathrm{L}$.

Clerodendrum indicum (L) Kuntze

Commelina benghalensis L.

Commelina paludosa Blume

Cynodon dactylon. (L.) DC.

Cyperus difforms $\mathrm{L}$.

Cyperus esculenta $\mathrm{L}$.

Cyperus iria $\mathrm{L}$.

Cyperus rotundus $\mathrm{L}$.

Dactyloctenium aegyptium (L.) Gaertn.

Desmodium triflorum (L.) DC.

Digitaria ciliaris (Retz.) Koeler

Digitarias anguinalis (L.) Scop.

Eclipta prostrata (L.)

Elsholtzia eriostachya (Benth.)

Elusine indica (L.) Gaertn.

Epatorium adenophorum L.

Eqisetum debile (Rox)

Eragrotis tenella (Retz.) Stapf.

Eragrotis unioloids (Retz.)NeesexSteud.

Euphorbia hirta L.

Evolvulus nummularis (L.) L.

Fimbristylis miliacea (L.) Vahl

Fimbristylis ovata (N.L.Burman) Kern.

Ficus benghalensis (Linn.)

Hemigrapis hirta $\mathrm{L}$.

Imperata cylindrical (L.) P. Beauv

Ipomea aquatica Forssk.

Lathyrus aphaca $\mathrm{L}$.

Lautana camera (L.) Moldenke

Lidwigia perennis $\mathrm{L}$.

Linder niaprocumbens (Krock.)Borbas

Lippia nudiflora (L.) Rich

Marsilea minuta L.

Mecardoni aprocumbens (Miller) Small

Mimosa pudica L.

$\begin{array}{lllllll}\text { Chenopodiaceae } & - & - & 6.3 & 18.4 & 0.3 & 3.9 \\ \text { Menispermaceae } & 2.0 & 4.1 & - & - & 0.3 & 3.6 \\ \text { Labiatae } & 2.6 & 4.3 & 0.3 & 3.0 & 2.0 & 4.1 \\ \text { Commelinaceae } & 2.6 & 4.2 & 7.0 & 17.8 & 2.0 & 4.1 \\ \text { Commelinaceae } & 8.7 & 17.4 & 5.3 & 17.5 & 2.6 & 4.2 \\ \text { Poaceae } & 19.7 & 18.7 & 14.7 & 19.3 & 19 . & 19.0 \\ \text { Cyperaceae } & 2.0 & 4.14 & 2.0 & 4.41 & 3.0 & 4.3 \\ \text { Cyperaceae } & 2.6 & 4.2 & 4.0 & 4.8 & 10.0 & 17.7 \\ \text { Cyperaceae } & 2.3 & 4.18 & 8.7 & 18.2 & 4.3 & 4.4 \\ \text { Cyperaceae } & 13.7 & 18.0 & 13.0 & 19.0 & 29 & 42.8 \\ \text { Poaceae } & 6.0 & 17.1 & 13.0 & 19.0 & 6.7 & 17.3 \\ \text { Leguminosae } & 7.0 & 17.2 & 8.66 & 18.2 & 12.6 & 26.3 \\ \text { Poaceae } & 10.3 & 17.6 & 9.3 & 18.3 & 7.3 & 17.3 \\ \text { Poaceae } & 3.6 & 4.34 & 8.3 & 5.6 & 17.7 & 18.7 \\ \text { Asteriaceae } & 6.3 & 17.1 & 11.0 & 18.6 & 2.3 & 4.2 \\ \text { Labiatae } & 5.3 & 17.0 & 5 & 16.7 & 3.6 & 4.4 \\ \text { Poaceae } & 4.3 & 4.4 & 9.6 & 18.4 & 8.6 & 17.5 \\ \text { Asteraceae } & 10.0 & 17.6 & 3.3 & 4.6 & 5.6 & 17.1 \\ \text { Eqisetaceae } & 1.3 & 4.0 & - & - & 0.3 & 3.0 \\ \text { Poaceae } & 0.6 & 3.0 & - & - & 0.3 & 17.7 \\ \text { Poaceae } & 2.0 & 4.1 & 7.6 & 18.0 & 9.0 & 17.6 \\ \text { Euphorbiaceae } & 5.33 & 17.0 & 6.3 & 22.5 & 18.6 & 17.3 \\ \text { Convolvulaceae } & 32.3 & 42.8 & 9.3 & 18.3 & 46.6 & 45.1 \\ \text { Cyperaceae } & 4.0 & 4.3 & 10.3 & 18.5 & 3.6 & 4.4 \\ \text { Cyperaceae } & 1.3 & 4.1 & 4.0 & 4.8 & 4.3 & 4.5 \\ \text { Moraceae } & 0.6 & 3.5 & - & - & 0.3 & 3.0 \\ \text { Acanthaceae } & 8.3 & 17.4 & 6.0 & 17.6 & 7.3 & 17.3 \\ \text { Poaceae } & 4.0 & 4.3 & 1.3 & 4.2 & 9.0 & 17.6 \\ \text { Convolvulaceae } & 3.3 & 4.3 & 2.0 & 4.4 & - & - \\ \text { Leguminosae } & 2.3 & 4.2 & 8.6 & 18.2 & 12.6 & 5.6 \\ \text { Verbenaceae } & 4.0 & 4.3 & - & - & 2.0 & 4.1 \\ \text { Onagraceae } & - & - & 4.0 & 4.8 & - & - \\ \text { Scrophulariaceae } & - & - & 8.0 & 18.0 & 6.0 & 17.2 \\ \text { Verbenaceae } & 10.3 & 17.6 & 9.3 & 18.3 & 6.0 & 17.2 \\ \text { Marsileaceae } & 0.3 & 3.0 & 7.6 & 18.0 & 0.6 & 3.0 \\ \text { Leguphulariaceae } & 20.6 & 4.3 & 6.3 & 17.9 & 4.6 & 4.5 \\ & 1.6 & 3.6 & - & - & 6.0 & 17.2\end{array}$


Murdannianudiflora (L.) Brenan

Oplimenus burmanii (Retz.) P. Beauv.

Oxalis corniculata L.

Parthenium hysterophorus L.

Paspalidium flavidum (Retz.) A. Camus

Paspalum conjugatum Berg.

Persicari abarbata (L.) Hara

Phyllanthus urinaria $\mathrm{L}$.

Portulica oleracea L.

Primula veris(L.)

Rumex nepalensis Sprenge

Scoparia dulcis L.

Senecio vulgaris $\mathrm{L}$.

Setaria glauca Beauv.

Sida acuta Burm. f.

Sida rhombifolia L.

Solanum nigrum (L.)

Solanum xanthocarpum Sachrad and Wendl

Sonchus asper (L.) Hill

Syzygium cumini (L)Skeels

Tridax procumbens $\mathrm{L}$.

Trifolium repens $\mathrm{L}$.

Urena sinuate L.

Xanthium strumarium L.

Zizyphus mauritiana Lam

\begin{tabular}{lllllll} 
Commelinaceae & - & - & 7.0 & 18.0 & 5.0 & 17.0 \\
Poaceae & 1.66 & 3.6 & 4.6 & 4.9 & 2.0 & 4.1 \\
Oxalidaceae & 18.6 & 17.2 & 5.6 & 17.6 & 7.3 & 17.3 \\
Asteraceae & 396.0 & 146.9 & 135.3 & 125.9 & 303.6 & 139.7 \\
Poaceae & 1.6 & 3.6 & 2.3 & 4.4 & 1.3 & 3.6 \\
Poaceae & 2.0 & 4.1 & 2.6 & 4.5 & 4.6 & 4.5 \\
Polygonaceae & 5.6 & 17.0 & 1.3 & 3.7 & 2.6 & 4.2 \\
Euphorbiaceae & 2.3 & 4.2 & 4.3 & 16.8 & 3.6 & 4.4 \\
Portulaceae & 9.0 & 17.4 & 4.3 & 4.8 & 9.0 & 17.6 \\
Primulaceae & 2.3 & 4.1 & 2.0 & 3.9 & 4.6 & 4.5 \\
Polygonaceae & 11.0 & 4.2 & 1.3 & 3.7 & 8.6 & 17.5 \\
Scrophulariaceae & 2.3 & 3.7 & 1.6 & 3.8 & 6.0 & 4.3 \\
Compositeae & 6.0 & 17.1 & 5.0 & 17.5 & 8.0 & 17.4 \\
Poaceae & 3.3 & 4.3 & 7.0 & 17.8 & 10.6 & 17.8 \\
Malvaceae & 5.6 & 17.0 & 2.6 & 4.5 & 2.6 & 4.3 \\
Malvaceae & 5.7 & 17.0 & 4.0 & 4.8 & 1.0 & 3.4 \\
Solanaceae & 3 & 4.2 & 4.3 & 4.9 & 2.7 & 4.2 \\
Solanaceae & 8.3 & 17.4 & 5.0 & 17.5 & 3.0 & 4.3 \\
Solanaceae & 4.3 & 4.4 & 2.0 & 4.4 & 7.0 & 17.3 \\
Myrtaceae & 1.3 & 3.4 & 0.7 & 3.1 & 0.6 & 3.5 \\
Asteraceae & 0.7 & 3.5 & 1.0 & 3.7 & 1.3 & 4.1 \\
Leguminosae & 3.3 & 4.3 & 7.3 & 17.9 & 9.7 & 17.7 \\
Malvaceae & 1.7 & 4.1 & 0.6 & 3.1 & 1.0 & 3.4 \\
Asteraceae & 4.0 & 4.4 & 0.6 & 3.1 & 1.3 & 4.1 \\
Rhamnaceae & 12.0 & 17.8 & - & - & 0.7 & 3.5 \\
& 396.6 & - & 135.3 & - & 303.7 & - \\
\hline - & & & & & &
\end{tabular}

$\mathrm{D}=$ Density, IVI= Importance Value Index.

Species Composition: The density and composition of plant species (Table 1) with Parthenium at site $1 ; 396.6 \mathrm{~m}^{-2}$, at site $2 ; 135.3 \mathrm{~m}^{-}$ 2 and at site $3 ; 303.7 \mathrm{~m}^{-2}$ indicate that agro-site has lower species density than the other two sites. In the road site the maximum density was contributed by Evolvulus nummularis (32.3 $\mathrm{m}^{-2}$ ), and the least density was contributed by Marsilea minuta $\left(0.3 \mathrm{~m}^{-2}\right)$. Similarly, at agrofield the maximum density was contributed by Cynodon dactylon $\left(14.7 \mathrm{~m}^{-2}\right)$ and least density was contributed by Clerodendrum indicum, Azadirecta indica and Centella asiatica (0.3 $\mathrm{m}^{-2}$ ). In the public place the maximum density was contributed by Evolvulus nummularis $\left(46.6 \mathrm{~m}^{-2}\right)$ and the least density was contributed by Artemisia vulgaris, Chenopodium album, Cissampelos pareira, Eqisetum debile and Eragrotis tenella with density $0.3 \mathrm{~m}^{-2}$.Some of the similarities of present survey agrees with the finding of Bhatt et al. 2007 in Far Western Nepal. 
Socio-economic Survey: In the present study, socio-economic surveys were conducted in all study areas using open ended, semi structured questionnaires involving farmers, cattle grazers, fodder collectors, community forest users' group, and health workers, to understand the public opinions. By grazing cattle on Parthenium invaded areas, $46 \%$ noticed health problems for cattle such as skin allergies, wounds, eye redness, and wounds around the mouth, loss of thirst and loss of appetite. Most of the fodder collectors from each site noticed allergy when the body surface came to contact with dew present in Parthenium leaves. More health risks were noticed during sunny days too. Among forest user it was noticed that the disappearance of Cassia tora, Ageratum haustorium, Cyperus rotundas, Euphorbia hirta, Cynodon dactylon, Dactyloctenium aegyptium, Amaranthus spinosus etc and many herb species due to its infestation. From health worker it was recorded that allergic problems of throats and skin for cattle were mostly documented (55\%) during the summer season at all sites. About 44 $\%$ of veterinary doctors of all sites used Avil injection and Flexona for the allergic treatments of animals and found effective.

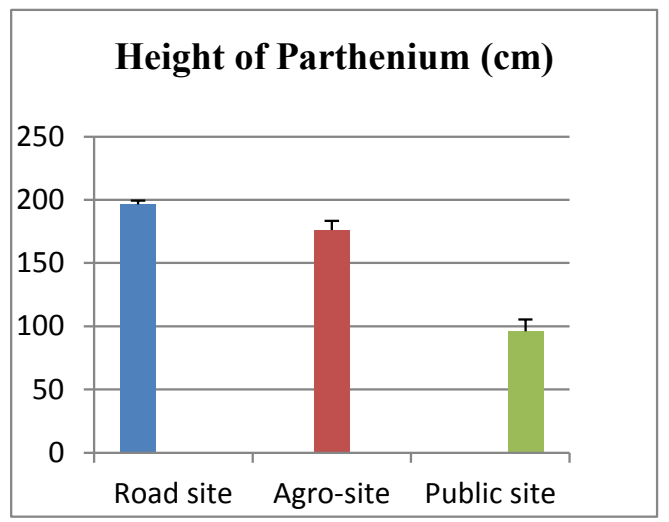

Fig. 1: Height of Parthenium at different sites

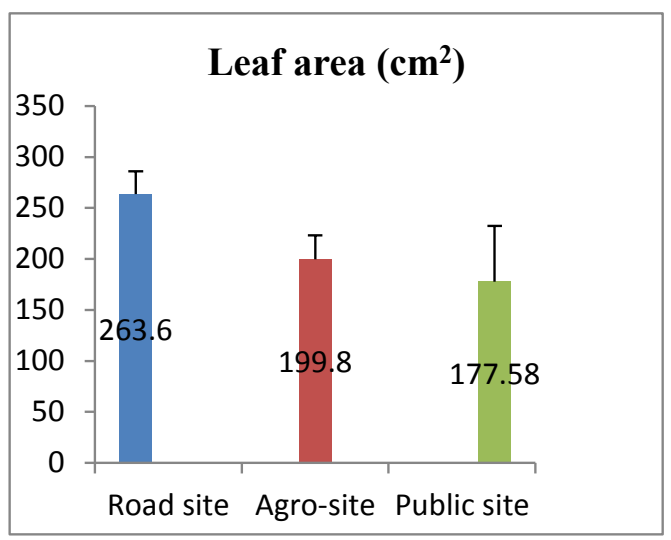

Fig. 2: Leaf area of Parthenium at different sites

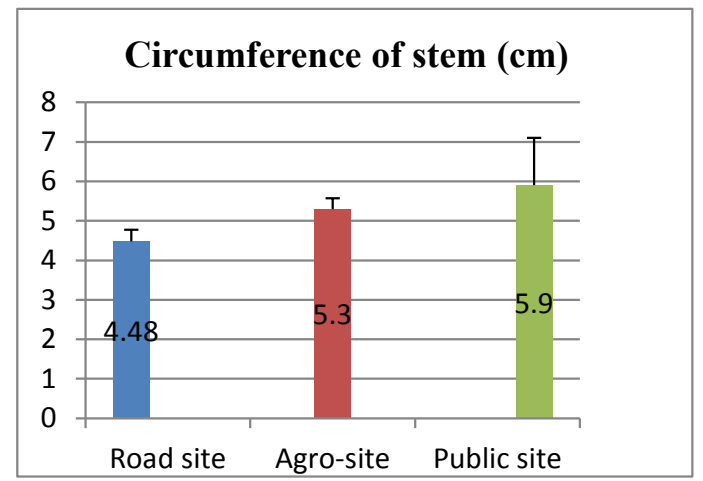

Fig. 3: Circumference of Parthenium at different sites

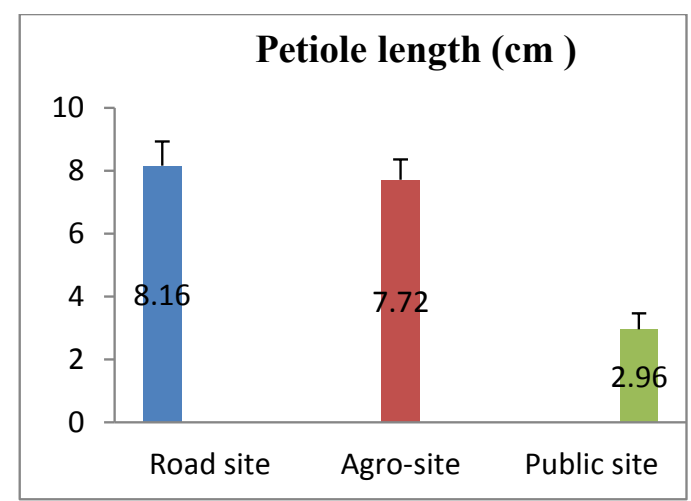

Fig. 4: Petiole length of Parthenium at different sites Ecological study of Parthenium: The average height of the Parthenium was recorded $196.4 \pm 2.96 \mathrm{~cm}, 176 \pm 7.50 \mathrm{~cm}$ and $96.0 \pm 9.31$ $\mathrm{cm}$ at road site, agro field and public places, respectively (Fig. 1).The highest leaf area was 
recorded at the road side, i.e. $263.6 \pm 22.26 \mathrm{~cm}^{2}$ and minimum at public places $(177.58 \pm 54.64$ $\mathrm{cm}^{2}$ ) (Fig. 2). Similarly, the maximum mean length of the petiole was recorded $8.16 \pm 0.77$ $\mathrm{cm}$ at road site and the minimum length 2.96 $\pm 0.51 \mathrm{~cm}$ at public places site. Petiole length at agro site was recorded $7.72 \pm 0.64 \mathrm{~cm}$ (Fig. 3). The mean of the circumference of the stem was recorded highest at road site $5.9 \pm 1.20 \mathrm{~cm}$ and lowest at public places $4.48 \pm 0.29 \mathrm{~cm}$ (Fig. 4).

\section{DISCUSSION}

The present distribution of Parthenium in Nepal covers most urban areas in tropical to sub-tropical regions at altitudes ranging from 75 to $1350 \mathrm{~m}$ (Tiwari et al., 2005). Because of the invasive nature, Parthenium is spreading rapidly along roadsides, fallow lands, and range lands in urban areas and it is gradually invading agricultural lands and forest in Nepal (Joshi, 2005; Timilsina, 2007; Shrestha, 2008). The composition of plant species with Parthenium was varied among the different sites. In the present survey, 80 plant species from different 31 families including Parthenium hysterophorus were studied in all study site. Among them 75 (93.75\%) species of plant with Parthenium were recorded from road site. Similarly, 73 (91.25\%) and $77(96.25 \%)$ plant species were recorded among agro-site and public site, respectively. In road site Bacopa monnieri, Chenopodium album, Ludwigia perennis, Lindernia procumbens, Murdannia nudiflora species were absent, whereas Mimosa pudica, Lantana camera, Ficus benghalensis, Equisetum debile, Cissampelos pareira, Achyranthes aspera, Zizyphus mauritiana were absent in agro-field. Similarly, Ludwigia perennis, Ipomea aquatica, Azadirachta indica species were absent at public park site. Due to the favorable conditions for seed dispersal mode, high disturbance on natural vegetation cover, the low fertility of soil and the dry habitat around the industrial areas and road sides, invasion might be high in those sites. The common species of plant found in all sites were Evolvulus nummuralus, Cynodon dactylon, Oxalis corniculata, Ageratum haustorium, Cannabis sativa, Amaranthus spinosus, Amaranthus virudus. The dominant families were found to be Poaceae (15\%), Asteraceae (11.25\%), Cyperaceae (7.5\%), Leguminosae (6.25\%), Amaranthaceae (5\%), and Commelinaceae (3.75\%).

The Evolvulus nummarulus might have strong association or competitive vigour with Parthenium hysterophorus. Karki (2009) reported Xanthium strumarium as most competitive species with Parthenium. But Azadirachta indica, Cissampelos pareira, Cyperus difforms, Equisetum debile, Ficus benghalensis, Ipomea aquatica, Launtana camera, Ludwigia perennis, Paspalidium flavidum, Tridax procumbens, Urena sinuate, were negatively affected by Parthenium invasion. Suppression of these species, in their growth and seed germination might be due to the lower competitive vigor of those species against Parthenium hysterophorus. Timlsina (2007) reported Trifolium repens, Imperata cylindrica and Dactyloctenium aegypticum as affected by Parthenium invasion and abundance of palatable species decreased with possible impact on fodder supply. Ahmed (2003) and Belaynesh (2006) indicated that due to this new invader (Parthenium) in the area, most of the valuable species are disappearing as a consequence there was forage scarcity. Similar problem was reported from the pastoral areas of central Queensland where Parthenium was the dominant species under certain conditions by producing negative effects on the growth and performance of the associated beneficial forage plant species. 
Density of Parthenium hysterophorus was found to be $396.7 \mathrm{~m}^{-2}, 135.3 \mathrm{~m}^{-2}$ and $303.7 \mathrm{~m}^{-2}$ at road site, agro site and public site, respectively. It might be due to the high seed dispersion by the movement of vehicles and abandonment of land in road site areas. Species richness found decreasing on increasing Parthenium's density. Adkins and Sowerby (1996) experimentally proved that Parthenium have allopathic effect in its root and shoot leachates and thus has the ability to reduce growth and germination of numerous associated species. Mechanism of decrease of species richness is elaborated by Navie et al. (1996). Sometimes at early stage, Parthenium takes the form of rosette that requires suitable open area to grow, spreads rapidly to grow thus interfering the emergence of other seedlings.

Parthenium is responsible for health problems in cattle and human beings such as skin allergies, wounds, boils, and eye redness, wound around the mouth, loss of thirst and loss of appetite directly or indirectly. Feeding of the fodder from Parthenium invaded area spoiled both the quality and the quantity of milk and meat. Some people suggested that it would be better to prevent animals from feeding on Parthenium at least five days prior to slaughtering in order to minimize the risk of losing the meat quality (Ayele, 2007). A female livestock owner in Kirtipur Municipality who collected $P$. hysterophorus to be used as an animal bedding also developed a significant skin allergy (Shrestha, 2008). The accidental inclusion of $P$. hysterophorus within harvested fodder grasses has led some Nepalese farmers to abandon this practice of harvesting within invaded regions (Karki, 2009). During the early 1990s, farmers in Hetauda used this weed as animal bedding and subsequently for composting (Karki, 2009). However, they soon noticed lesions on their stock's skin, with buffaloes reported to be more sensitive than cattle.

The average height of Parthenium was recorded from range 96- $197 \mathrm{~cm}$. Shrestha (2008) reported Parthenium height $112 \mathrm{~cm}$ in his study held in Kathmandu valley. His finding is included within value range of our examined height. Kumariand Kohli (1987) reported Parthenium height as $150 \mathrm{~cm}$. Leaf area was obtained at range value of $170-263 \mathrm{~cm}^{2}$ from all study site. Although small in area, Nepal is exceptionally rich in biodiversity. The diverse climatic condition is very much favorable to grow and establish several kinds of flora and fauna. But the introduction of alien invasive species Parthenium, is suppressing the growth of various species. Our investigations demonstrate that agro field is less affected by Parthenium at present time i.e crops are less suppressed. More than $80 \%$ of Nepalese people depend upon agriculture for their socio- economy. What results if crop fields are also invaded by Parthenium as in many other countries? That's why its control becomes an urgent need to conserve socio economy. Long term management programs and awareness programs should be carried out to control this weed. Government should conduct well organized, co-ordinate and concerned efforts strictly to control or eliminate this weed. Local people also rise to control this weed in unison with NGO's, INGO's and other social institutions.

\section{ACKNOWLEDGEMENTS}

The First two authors are thankful to their supervisors Dr. M.D. Bhatt, Head, Department of Botany Siddhanath Science Campus, Mahendranagar, Nepal, for his cooperation in identification of plant species, manuscript preparation, overall supervision, and facilities through the project period. 


\section{REFERENCES}

Ahmed, B., (2003). Soil condition and vegetation cover in human impacted rangelands of Jijiga, Somali Regional State. An MSc Thesis Presented to the School of Graduate Studies of Alemaya University, Ethiopia. 108p.

Ayele, S. (2007). The Impact of Parthenium (Parthenium hysterophorus L.) on the Range Ecosystem Dynamics of the Jijiga Rangeland, Ethiopia [M. A. Dissertation] Department of Animal Sciences, School of Graduate Studies, Haramaya University. 117p.

Belaynesh Debalkie, (2006). Floristic composition and diversity of the vegetation, soil seed bank flora and condition of the rangelands of the Jijiga Zone, Somali Regional State, Ethiopia

Bhatt, M.D., S.P. Singh and A. Tewari (2007). Floristic composition and Phenology of major weed species associated with paddy fields in foothills of Far Western Nepal. Nepal Journal of Science and Technology 8: 27-33.

Chippendale, J. F. and F. D. Panetta (1994). The cost of Parthenium weed in Australia Cattle industry. Plant Protection Quarterly 9:73-76.

Curtis, J.T, and R.P. Mclntosh (1951). An upland forest continuum in the Prarie Forest border region of Wisconsin. Ecology 32: 476-96.

Joshi, S. (2005). Reproductive Efficiency and Biomass Allocation of Invasive weed, Parthenium hysterophorus L. [M.Sc. Dissertation]. Central Department of Botany, Tribhuvan University, Kathmandu, Nepal. 69 p.

Kanchan, S.D. (1975). Growth inhibitors from Parthenium hysterophorus L. Current Science. 44: 358-359.

Karki, D., (2009). Ecological and Socio-economic Impact of Parthenium hysterophorus L. Invasion in Two Urban Cities of South-Central Nepal [MSc theis]. Central Department of Botany, 338. J. Nat. Hist. Mus. 25, 2010 Tribhuvan University, Kathmandu.

Kathiresan, R. M. (2004). Invasive weeds in agroecosystems of South India [Abstracts]. In: National Workshop on Invasive Alien species and Biodiversity in India, Banaras Hindu University, Vanarasi, India. $149 \mathrm{p}$.

Kathiresan, R.M., I. Gnanavel, R. Anbhazhagan, S.P. Padmapriya, N.K. Vijayalaxmi and M.P.
Arulchezhian, (2005). Ecology and control of Parthenium invasion in command area. Proceedings of the $2^{\text {nd }}$ International Conference on Parthenium Management, December 5-7, 2005, Bangalore, India. pp:77-80.

Kololgi, P.D., S.D. Kololgi and M.P. Kololgi. (1997). Dermatologic hazards of Parthenium in human beings. In: Proceedings of first international conference on Parthenium management University of Agricultural Science, Dharwad, India. Pp. 18-19.

Kumari, A. and R. K. Kohli (1987). Autotoxicity of Ragweed Parthenium (Parthenium hysterophorus L.). Weed Science 35: 629-632.

Misra, R. (1968). Ecology Workbook. Oxford and IBH Publishing Co., New Delhi, India.

Navie, S. C., R. E. McFadyen, F. D. Panetta and S. W. Adkins (1996). The biology of Australian weeds 27. Parthenium hyterophorous L. Plant Protection Quaterly 11: 76-88.

Shrestha, B. B., (2008). Phailedai Hanikarak Banaspati [Nepali]. Kantipur National News $17^{\text {th }}$ May 2008. p10.

Sriama, R., S. Naggpal, B.S. Rao, O. Prakash and P.V. Rao (1991). Immediate hypersensitivity to Parthenium hysterophorus clinical studies on the prevalence of Parthenium rhinitis. Clinical Experiment Allergy, 21:55-62.

Timlsina, B. (2007). Impact of Parthenium hysterophorus L. Invasion on Soil and Plant species composition of Grasslands of Central Nepal. [M. Sc. Dissertation] Central Department of Botany, Tribhuvan University, Kathmandu, Nepal.

Timlsina, B., B.B. Shrestha, M.B. Rokaya and Z. Munzbergova. (2011). Impact of Parthenium hysterophorus L. invasion on plant species composition and soil properties of grassland communities in Nepal. Flora 206: 233-240.

Tiwari S., B. Adhikari, M. Siwakoti and K. Subedi (2005). An Inventory and Assessment of Invasive Alien Plant Species of Nepal. IUCN, Kathmandu, Nepal.

Zobel, D.B., P.K. Jha, N.J. Behan and U.K.R. Yadav. (1987). A practical manual for ecology. Ratna Book Distributors, Kathmandu, Nepal.

(Received 7 July 2017, revised accepted 19 Aug 2017) 